\title{
EVALUASI PEMANFAATAN MEDIA SOSIAL BAGI PELAKSANAAN FUNGSI ANGGOTA DPRD JAWA TENGAH
}

\author{
(EVALUATION IN SOCIAL MEDIA USING FOR \\ PERFORMING CENTRAL JAVA PARLIAMENT MEMBERS \\ FUNCTIONS)
}

\author{
Oleh: Nuriyatul Lailiyah ${ }^{1}$ dan Wahid Abdulrahman ${ }^{2}$ \\ ${ }^{1}$ Dosen Ilmu Komunikasi FISIP UNDIP, \\ E-mail: n.lailiyah@gmail.com \\ ${ }^{2}$ Dosen Ilmu Pemerintahan \& Ilmu Politik FISIP, \\ E-mail: 01abdulrahman@gmail.com
}

\begin{abstract}
Abstrak
Dalam rangka peningkatan kinerja DPRD Jawa Tengah media sosial digunakan sebagai sarana yang mudah, murah, dan bisa menjangkau berbagai lapisan masyarakat yang tersebar di seluruh wilayah Jawa Tengah. Penelitian ini bertujuan untuk mengevaluasi pemanfaatan media sosial dalam pelaksanaan fungsi anggota DPRD untuk berkomunikasi dengan masyarakat. Penelitian ini merupakan penelitian kualitatif dengan metode studi kasus. Pengambilan data melalui wawancara mendalam terhadap anggota DPRD Jawa Tengah yang aktif di media sosial dan masyarakat yang ada dalam jejaring mereka. Hasil penelitian terdiri dari tiga hal. Pertama, media sosial digunakan oleh anggota DPRD Jawa Tengah untuk tiga hal, antara lain: (1) mengkomunikasikan fungsi dewan (legislasi, pengawasan, dan anggaran); (2) berkomunikasi dengan publik dalam rangka mendengar aspirasi dan mendapatkan masukan; (3) sarana hiburan yang diwujudkan dengan menggunakan media sosial sebagai penyaluran ekspresi diri dan informasi kegiatan pribadi maupun dengan keluarga. Kedua, terkait fungsi dewan yang dikomunikasikan melalui media sosial, fungsi pengawasan merupakan fungsi yang paling sering dilakukan. Sementara fungsi legislasi dilakukan secara moderat, dan fungsi anggaran sebagai fungsi yang paling jarang dikomunikasikan. Ketiga, informan masyarakat yang ada dalam jaringan media sosial anggota DPRD Jawa Tengah yang aktif di media sosial mempersepsikan anggota dewan tersebut sebagai wakil rakyat yang benar-benar bekerja untuk rakyat.
\end{abstract}

Kata kunci: media sosial, anggota dewan, fungsi DPRD

\begin{abstract}
In order to improve the performance of Central Java Parliament, social media has been used as a tool that is easy, inexpensive, and could reach all segments throughout the region of Central Java. This study aimed to evaluate the use of social media in the implementation of the functions of legislators to communicate with the public. This research is a qualitative research with case study method. Capturing data through in-depth interviews to Central Java Parliament members who are active in social media and the public in their networks. The results of the study consisted of three things. First, social media is used by members of the Central Java Parliament for three reasons: (1) communicate the functions of the parliament (legislative, control, and budget); (2) communicate with the public in order to listen public needs and get feedback; (3) a means of self entertainment by using social media as a tool to express their selves and share personal information. Second, related to the function of the parliament which has been communicated through social media, the
\end{abstract}


control function is the most frequent performed. While the legislative function performed moderately, and the budget function as the most rarely communicated. Third, public informants in social media networks of Central Java parliament members perceives the them as representatives of the people who actually work for the people.

Keywords: social media, members of the board, the function of parliament.

\section{A. Pendahuluan}

\section{Latar Belakang}

Dewan Perwakilan Rakyat Daerah (DPRD) sebagai parlemen lokal di Indonesia memiliki peran yang penting dalam keberhasilan penyelenggaraan pemerintahan daerah. Undang-Undang No 23 Tahun 2014 tentang Pemerintahan Daerah menempatkan DPRD sebagai bagian dari penyelenggara pemerintahan daerah bersama pemerintah daerah. DPRD sendiri berperan sebagai lembaga perwakilan rakyat daerah sebagai unsur penyelenggara pemerintahan daerah yang memiliki fungsi pembentukan peraturan daerah (legislasi), anggaran, dan pengawasan. Selain itu DPRD memiliki tugas:

1) Membentuk Perda yang dibahas dengan kepala derah untuk mendapat persetujuan bersama.

2) Membahas dan menyetujui rancangan Perda tentang APBD bersama dengan kepala daerah.

3) Melaksanakan pengawasan terhadap pelaksanaan perda dan peraturan perundangan lainnya, peraturan kepala daerah, APBD, kebijakan pemerintah daerah dalam melaksanakan program pembangunan daerah, dan kerjasama internasional di daerah.

4) Mengusulkan pengangkatan dan pemberhentian kepala daerah/wakil kepala daerah kepada presiden melalui Mendagri bagi DPRD provinsi dan kepada Mendagri melalui Gubernur bagi DPRD kab/kota.

5) Memilih wakil kepala daerah dalam hal terjadi kekosongan jabatan wakil kepala daerah.

6) Memberikan pendapat dan pertimbangan kepada pemerintah daerah terhadap rencana perjanjian internasional di daerah.

7) Memberikan persetujan terhadap rencana kerja sama internasional yang dilakukan oleh pemerintah derah.

8) Meminta laporan keterangan pertanggungjawaban kepala daerah dalam penyelenggaraan pemerintahan daerah.

9) Membentuk panitia pengawas pemilihan kepala daerah.

10) Melakukan pengawasan dan meminta laporan KPUD dalam penyelenggaraan pemilihan kepala daerah.

11) Memberikan persetujuan terhadap rencana kerja sama antar daerah dan dengan pihak ketiga yang membebani masyarakat daerah.

Dalam rangka melaksanakan fungsi dan tugas tersebut DPRD menjaring aspirasi masyarakat sebagaimana amanat dari Pasal 96 Undang-undang No 23 Tahun 2014. Untuk menjalankan fungsi tersebut anggota DPRD dituntut untuk mampu berhubungan dengan 
Diterbitkan oleh Program Studi IImu Komunikasi

Universitas Ahmad Dahlan Yogyakarta

masyarakat secara berkesinambungan. Pola hubungan komunikasi antara anggota DPRD dapat dilakukan secara formal maupun informal. Secara formal anggota DPRD melakukan komunikasi melalui masa reses yang telah diatur dalam Tata Tertib DPRD. Sedangkan secara informal anggota DPRD dapat berkomunikasi dengan masyarakat melalui media sosial atau pertemuan-pertemuan yang diselenggarakan oleh masyarakat yang kemudian didatangi oleh anggota DPRD.

Hasil penelitian Wahid Abdulrahman ${ }^{1}$ masa reses DPRD Jawa Tengah belum sepenuhnya berjalan efektif. Dimana tidak semua masyarakat memiliki akses untuk mengikuti kegiatan reses DPRD, hanya sebagian kecil masyarakat yakni pengurus partai dan simpatisanlah yang paling memiliki akses untuk berkomunikasi dengan anggota DRPD. Akibatnya kemudian banyak aspirasi dari masyarakat yang tidak dapat tertampung oleh anggota DPRD. Penelitian tersebut juga menunjukkan bahwa masa reses banyak dimanfaatkan menjadi kegiatan konsolidasi internal partai. Sementara penelitian yang lebih baru terkait kinerja DPRD dalam menjalankan fungsinya menunjukkan bahwa kinerja DPRD Jawa Tengah dari fungsi legislasi sudah baik. Hal tersebut dapat dilihat dari jumlah Peraturan Daerah yang disahkan dan jumlah Peraturan Daerah yang merupakan usulan dari DPRD (perda inisiatif). Jumlahnya meningkat jika dibandingakan dengan periode-periode sebelumnya ${ }^{2}$.

Pada 11 Februari 2016 DPRD Jawa Tengah memproklamirkan dirinya sebagai Parlemen Terbuka dan Modern yang dicanangkan dalam kegiatan yang dihadiri oleh Menteri Dalam Negeri dan perwakilan DPRD Provinsi se-Indonesia ${ }^{3}$. Salah satu ciri dari parlemen modern adalah kemudahan masyarakat dalam mengakses informasi sekaligus berkomunikasi dengan anggota DPRD. Dalam rangka memudahkan masyarakat untuk berkomunikasi dengan anggota DPRD Jawa Tengah, ketua DPRD Jawa Tengah menghimbau anggotanya untuk memiliki akun di media sosial ${ }^{4}$. Pada tataran itulah peran media sosial sangat penting.

Penelitian ${ }^{5}$ menunjukkan bahwa anggota DPRD Jawa Tengah menggunakan berbagai media untuk berkomunikasi dengan masyarakat yang mereka wakili. Beberapa media yang digunakan antara lain, melalui pemberitaan di media massa, bertemu langsung dengan konstituen di lapangan, dan menggunkan media sosial.

Pemberitaan di media massa bagi anggota dewan dipandang mampu meningkatkan perhatian pemerintah atau eksekutif atas isu yang disampaikan anggota dewan. Selain itu

\footnotetext{
${ }^{1}$ Abdulrahman, Wahid. Evaluasi Masa Reses DPRD Jawa Tengah. Tesis. Magister Ilmu Politik Universitas Diponegoro, 2011. (unpublished)

${ }^{2}$ Abdulrahman, Wahid. "Evaluasi Badan Legislasi DPRD Jawa Tengah.” Politika: Jurnal Ilmu Politik. Vol 6 (1 April 2015): 74-84, ISSN: 2086-7344, Magister Ilmu Politik Program Pascasarjana Universitas Diponegoro, 2015.

3 Humas. "DPRD Jateng Menuju Parlemen Terbuka.", 10 Februari 2016, http://wartalegislatif. dprd.jatengprov.go.id/ post/dprd-jateng-menuju-parlemen-terbuka

${ }^{4}$ Ayudea, Fani. “Anggota DPRD Harus Punya Akun Media Sosial.” Suara Merdeka, 11 Februari 2016, http://berita.suaramerdeka.com/anggota-dprd-harus-punya-akun-media-sosial/

${ }^{5}$ Lailiyah, Nuriyatul. "Strategi Media Relations Politisi untuk Meraih Popularitas di Media Massa." Politika: Jurnal Ilmu Politik vol 6 (1 April 2015): 93-103, ISSN: 2086-7344 Magister Ilmu Politik Program Pascasarjana Universitas Diponegoro.
} 
berkomunikasi melalui media massa juga sekaligus memberi kesempatan pada anggota dewan untuk menyampaikan pada masyarakat bahwa mereka sedang memperjuangkan aspirasi masyarakat. Namun kelemahan dari komunikasi melalui media cetak adalah tidak interaktif. Sehingga anggota dewan tidak bisa mendapatkan masukan atau respon secara langsung.

Cara ketiga yang digunakan untuk berkomunikasi dengan masyarakat adalah melalui kegiatan tatap muka langsung dengan masyarakat seperti saat kegiatan reses anggota dewan. Kegiatan tatap muka memiliki kekurangan karena membutuhkan waktu dan biaya yang relatif besar. Selain itu kegiatan tatap muka tidak bisa menjangkau orang banyak dari lokasi berbeda pada waktu yang sama. Berbagai kelemahan media komunikasi tersebut dilengkapi dengan kehadiran media sosial.

Media sosial memiliki sifat interaktif, murah, bisa menjangkau secara serentak ke banyak orang maupun personal. Melakukan komunikasi dengan baik melalui media sosial berarti juga bagian dari menjaga dan mempertahankan kepercayaan masyarakat. Tidak dapat dipungkiri bahwa politisi cenderung mencalonkan kembali dalam periode berikutnya ketika menjadi wakil rakyat. Data dari Lembaga Pemilih Indonesia menunjukkan 90,5\% anggota DPR RI periode 2004-2009 mencalonkan kembali menjadi wakil rakyat pada pemilihan umum 2009 untuk periode 2009-2014 ${ }^{6}$. Hal ini membuat para wakil rakyat memiliki kesempatan yang baik untuk secara konsisten berkomunikasi dengan masyarakat.

Di samping dalam menjalankan fungsi sebagai anggota dewan, kehadiran media sosial mendekatkan anggota dewan dengan masyarakat yang diharapkan akan kembali memilih mereka sebagai wakil pada periode pemilihan berikutnya. Potensi media sosial yang besar sebagai media komunikasi yang murah, mudah, dan menjangkau banyak lapisan masyarakat di berbagai penjuru berpotensi menurunkan biaya kampanye yang selama ini dinilai terlalu mahal dibandingkan dengan pendapatan resmi anggota dewan bila terpilih.

Hasil riset Lembaga Penyelidikan Ekonomi dan Masyarakat Universitas Indonesia (LPEM UI) mengungkapkan bahwa seorang caleg DPR rata-rata harus mengeluarkan dana sebesar Rp.1,18 miliar untuk melakukan kampanye agar dapat menduduki kursi legislatif. Dana kampanye tersebut dinilai merupakan nilai yang wajar. Sementara pendapatan yang diperoleh anggota DPR selama lima tahun yakni Rp.5,3 miliar - Rp.5,4 miliar. Sementara pendapatan seorang anggota DPRD provinsi yakni Rp.1,6 miliar - Rp.1,8 miliar. Rentang pendapatan tersebut berasal dari pendapatan resmi maupun tidak resmi. Berikut rincian jumlah biaya kampanye dari calon legislatif yang berkampanye untuk pemilihan legislatif tahun 2014?:

\footnotetext{
${ }^{6}$ Budilaksono, Imam. “90,5\% Anggota DPR Mencalonkan Kembali.”, Antara News, 5 Maret 2013, http://www.antaranews.com/berita/373085/905-persen-anggota-dpr-mencalonkan-kembali

${ }^{7}$ Antara. "Hasil Riset, ini Jumlah Rata-rata Dana Kampanye Caleg DPR.", Republika, 19 Maret 2014, http://www.republika.co.id/berita/nasional/politik/14/03/19/n2o11c-hasil-riset-ini-jumlah-ratarata-danakampanye-caleg-dpr
} 
Diterbitkan oleh Program Studi IImu Komunikasi

Universitas Ahmad Dahlan Yogyakarta

Tabel 1. Jumlah Biaya Kampanye Calon Legislatif

\begin{tabular}{|l|l|l|l|l|l|}
\hline \multicolumn{1}{|c|}{ Tingkat } & \multicolumn{1}{|c|}{ Sedikit } & \multicolumn{1}{c|}{ Optimal } & \multicolumn{1}{c|}{ Wajar } & \multicolumn{1}{c|}{$\begin{array}{c}\text { Tidak } \\
\text { Wajar }\end{array}$} & $\begin{array}{c}\text { Tidak } \\
\text { Rasional }\end{array}$ \\
\hline DPR RI & $<$ Rp. 787 & Rp.787 & Rp. 1,18 & Rp. 4,6 & >Rp.9,3 \\
& Juta & Juta - & Milyar - & Milyar - & Milyar \\
& & $\begin{array}{l}\text { Rp.1,18 } \\
\text { milyar }\end{array}$ & $\begin{array}{l}\text { Rp.4,6 } \\
\text { Milyar }\end{array}$ & $\begin{array}{l}\text { Rp.9,3 } \\
\text { Milyar }\end{array}$ & \\
\hline DPRD & <Rp.320 & Rp.320 Juta & Rp. 481 & Rp. 1,55 & $>$ Rp.3 \\
Propinsi & Juta & - Rp.481 & Juta - & Milyar - & Milyar \\
& & Juta & Rp.1,55 & Rp.3 Milyar & \\
& & & Milyar & & \\
\hline
\end{tabular}

Sumber: Antara, 2014.

Hasil penelitian di atas semakin menguatkan pentingnya penggunaan media sosial sebagai media yang mudah sekaligus murah untuk sarana komunikasi anggota dewan dengan masyarakat. Namun sejauh ini belum ada penelitian terkait efektivitas pemanfaatan media sosial dalam mendukung kinerja anggota DPRD yang menggunakan media sosial. Padahal saat ini seluruh anggota DPRD Jawa Tengah diharapkan sudah memiliki media sosial. Hal ini menunjukkan perlunya dilakukan penelitian terkait evaluasi pemanfaatan media sosial bagi pelaksanaan fungsi anggota DPRD Jawa Tengah.

a. Rumusan masalah

Komitmen untuk menjadi parlemen terbuka yang dicanangkan oleh DPRD Jawa Tengah menjadi momentum bagi anggota dewan untuk menjadi lebih terbuka dan komunikatif pada masyarakat. Komitmen tersebut disertai himbauan dari ketua DPRD Jawa Tengah agar seluruh anggota DPRD menggunakan media sosial sebagai sarana berkomunikasi dengan masyarakat dalam rangka menjalankan tugas dan fungsinya sebagai anggota DPRD. Sejak sebelum ada himbauan dari ketua DPRD, sebagian anggota DPRD sudah menggunakan media sosial untuk mendukung pelaksanaan tugas dan fungsi yang mereka miliki ${ }^{8}$. Penelitian terdahulu tentang kinerja DPRD Jawa Tengah dalam melaksanakan tugas dan fungsi menunjukkan terjadinya peningkatan kinerja ${ }^{9}$ yang terlihat dari kenaikan jumlah peraturan daerah yang berhasil dihasilkan oleh DPRD Jawa Tengah.

Dalam rangka peningkatan kinerja DPRD Jawa Tengah itulah media sosial kemudian dapat digunakan sebagai sarana yang mudah, murah, dan bisa menjangkau berbagai lapisan masyarakat yang tersebar di seluruh wilayah Jawa Tengah. Keuntungan komunikasi melalui media sosial jika dilakukan secara efektif bisa mendorong berkurangnya biaya komunikasi dalam pemilihan legislatif periode berikutnya. Hal tersebut mengingat hasil riset Lembaga Pemilih Indonesia bahwa 90,5\% anggota dewan mencalonkan kembali pada

${ }^{8}$ Lailiyah, Nuriyatul. "Strategi Media Relations Politisi untuk Meraih Popularitas di Media Massa." Politika: Jurnal Ilmu Politik vol 6 (1 April 2015): 93-103, ISSN: 2086-7344 Magister Ilmu Politik Program Pascasarjana Universitas Diponegoro.

${ }^{9}$ Abdulrahman, Wahid. "Evaluasi Badan Legislasi DPRD Jawa Tengah.” Politika: Jurnal Ilmu Politik. ISSN: 2086-7344, Magister Ilmu Politik Program Pascasarjana Universitas Diponegoro, 2015. 
periode berikutnya ${ }^{10}$. Sementara selama ini biaya pencalonan anggota dewan cenderung mahal dan banyak habis untuk biaya kampanye offline.

Namun sejauh ini belum ada evaluasi bagaimana pemanfaatan media sosial dalam pelaksanaan fungsi anggota DPRD untuk berkomunikasi dengan masyarakat. Karena itulah penelitian ini dilakukan untuk menjawab pertanyaan bagaimana efektivitas media sosial bagi pelaksanaan fungsi anggota DPRD Jawa Tengah.

b. Tujuan Penelitian

Penelitian ini bertujuan untuk mendeskripsikan hal-hal berikut:

1) Komunikasi yang dilakukan anggota DPRD Jawa Tengah melalui media sosial

2) Sejauh mana pemanfaatan media sosial oleh anggota DPRD Jawa Tengah dalam melaksanakan fungsinya.

3) Persepsi masyarakat terhadap anggota DPRD Jawa Tengah dalam media sosial

c. Kerangka Pemikiran

State of the art

Penelitian terkait media yang digunakan oleh anggota parlemen untuk berkomunikasi dengan masyarakat. Beberapa yang digunakan adalah media cetak. Media cetak adalah salah satu yang digunakan sebagai media berkomunikasi anggota parlemen ${ }^{11}$. Kiambi meneliti penggunaan media cetak oleh anggota parlemen di Kenya menghadapi tuduhan pelanggaran terkait korupsi dan pelanggaran jabatan lain. Dengan metode analisis teks ditemukan bahwa strategi retorika apologi digunakan baik oleh individual maupun organisasi untuk merespon tuduhan penyalahgunaan wewenang di Kenya. Anggota parlemen menggunakan strategi penyangkalan, viktimisasi, mortifikasi, dan perlawanan dibanding strategi lain. Satu strategi yang paling banyak muncul digunakan oleh politisi Kenya adalah dengan memanfaatkan isu etnis.

Menggunakan public relations adalah salah satu cara yang juga bisa digunakan politisi untuk berkomunikasi dengan masyarakat. Salah satu aktivitas public relations yang bisa digunakan adalah dengan menunjukkan komitmen bekerja sesuai kewajibannya yaitu aktif dalam kegiatan parlemen. Bernecker ${ }^{12}$ meneliti tentang tingkat aktivitas anggota parlemen Jerman. Dengan menggunakan analisis mikro peneliti mengkaji terkait kompetisi elektoral yang ketat dan pengaruhnya terhadap kelalaian politik. Dengan menggunakan data sepanjang tahun 2005-2012 yang mencakup informasi biografis dan politis anggota parlemen Jerman, termasuk tingkat kehadiran mereka dalam sesi pengambilan suara. Bagi parlemen yang terpilih pada tahun 2009, terlihat bahwa partai oposisi parlemen Jerman yang

${ }^{10}$ Budilaksono, Imam. “90,5\% Anggota DPR Mencalonkan Kembali.”, Antara News, 5 Maret 2013, http://www.antaranews.com/berita/373085/905-persen-anggota-dpr-mencalonkan-kembali

${ }^{11}$ Kiambi, Dane. "Ethnic Appeal: A Self-defense Tool for Kenyan Politicians." Public Relations Review, 38 (2012): 144-146.

12 Bernecker, Andreas. "Do Politicians Shirk when Relection is Certain? Evidence from The German Parliament.” European Journal of Political Economy 36 (2014): 55-70. 
Diterbitkan oleh Program Studi IImu Komunikasi

Universitas Ahmad Dahlan Yogyakarta

bersiap menghadapi kompetisi yang ketat di distrik mereka menunjukkan tingkat ketidakhadiran yang signifikan rendah di parlemen sebelumnya. Anggota parlemen dari partai berkuasa tidak bereaksi secara signifikan pada kompetisi elektoral. Hasil tersebut dikonfirmasi dengan analisis pada anggota parlemen yang terpilih pada tahun 2005, dengan beberapa pengecekan yang kuat, dan dengan menggunakan strategi variabel intal yang mengeksploitasi kekhasan yang mudah dari sistem elektoral Jerman. Hasil penelitian juga menunjukkan bagaimana anggota parlemen yang terpilih melalui partai bereaksi pada tingkat yang berbeda dalam kompetisi elektoral ${ }^{13}$ (Bernecker, 2014).

Penggunaan public relations sebagai alat komunikasi juga terkait dengan optimalisasi "kehadiran" baik di dunia nyata maupun dunia maya. Kehadiran anggota parlemen di dunia maya menjadi kajian Lim \& Park ${ }^{14}$. Visibilitas web dari politisi memiliki implikasi positif bagi internet dan politik. Terkait itu, dilakukan penelitian terhadap visibilitas web dari anggota Majelis Nasional Korea Selatan ${ }^{15}$ ke-18. Penelitian mengkaji anggota parlemen dengan web visibilitas tertinggi dan menentukan faktor-faktor yang mempengaruhi web visibilitas mereka dengan menggunakan seperangkat variabel yang menunjukkan visibilitas web. Konsep visibilitas web secara operasional didefinisikan sebagai jumlah web mention ${ }^{16}$ dari tiap anggota kongres. Web mentions dari nama tiap anggota kongres dikumpulkan melalui berbagai platform termasuk blog, gambar, berita, dan situs dengan menggunakan alat pencarian Naver berdasar pada API ${ }^{17}$, dan hubungan antara visibilitas web anggota kongres dengan atribut sosio-demografis mereka (gender, jenis kelamin, istilah, konstitusi, dan afiliasi partai) dianalisis dengan uji $\mathrm{U}$ Kruskal-Wallis, Median, dan Mann-Whitney. Politisi yang paling nampak di dunia web Korea memiliki kualifikasi ketenaran dan karir politik yang tinggi. Perbedaan pada visibilitas web politisi tergantung pada atribut politik mereka (istilah yang digunakan, konstituensi, dan partai), bukan pada atribut demografis mereka (gender dan usia). Temuan ini menyarankan agar politisi yang membangun kekuatan dan pengaruh politik melalui karir politik di dunia nyata cenderung lebih

${ }^{13}$ Bernecker, Andreas. "Do Politicians Shirk when Relection is Certain? Evidence from the German Parliament." European Journal of Political Economy 36 (2014): 55-70.

${ }^{14}$ Lim, Yon Soo \& Han Woo Park. "How Do Congressional Members Appear on The Web? Tracking the Web Visibility of South Korean Politicians." Government Information Quarterly, 28 (2011): 514-521.

${ }^{15}$ Parlemen di Korea Selatan

${ }^{16}$ Web mention adalah cara sederhana untuk menotifikasi URL apapun saat kita menempatkannya dalam situs kita. Dari perspektif penerima, ini adalah cara untuk meminta notifikasi ketika link lain membuat tautan pada web tersebut (https://indiewebcamp.com/Webmention). Contoh cara kerja web mention:

1) Alice menulis materi yang menarik pada situsnya (sudah dirancang untuk bisa menerima web mention)

2) Bob melihat konten Alice dan berkomentar tentangnya di situsnya sendiri dengan menautkan pada materi yang ditulis Alice.

3) Dengan web mention, software muatan Bob secara otomatis menotifikasi server Alice bahwa tulisannya ditautkan pada tulisan Bob di webnya.

4) Software muatan Alice memverifikasi bahwa dalam tulisan Bob benar-benar terdapat tautan ke tulisannya dan kemudian menampilkan informasi tersebut di web Alice sendiri.

${ }^{17}$ Application Programming Interface is a language and message format used by an application program to communicate with the operating system or some other control program such as a database management system (DBMS) or communications protocol (http://www.pcmag.com/encyclopedia/term/37856/api). 
terlihat di dunia web. Ke depan, indikator terintegrasi berdasar status visibilitas politisi dapat merefleksikan "kehadiran di mana-mana" mereka dalam masyarakat digital Korea ${ }^{18}$.

Riset-riset di atas menunjukkan berbagai media yang digunakan oleh politisi baik dalam konteks untuk berkomunikasi dengan masyarakat maupun dalam konteks melaksanakan pekerjaan mereka sebagai anggota parlemen. Dari pencarian yang dilakukan oleh peneliti melalui situs pencarian jurnal Science Direct, peneliti belum menemukan secara spesifik penelitian terkait penggunaan media sosial oleh anggota parlemen dalam rangka pelaksanaan tugas dan fungsi anggota parlemen.

\section{Evaluasi Pemanfaatan Media Sosial}

Media sosial dikatakan efektif sebagai sarana berkomunikasi ketika tujuan komunikasi tercapai. Peneliti melihat pesan yang dikirimkan oleh anggota dewan dalam media sosial mereka termasuk kategori pesan persuasi. Karena anggota dewan melakukan komunikasi dengan media sosial dengan tujuan menjalankan fungsinya sekaligus menjaga kepercayaan masyarakat. Pesan dalam media sosial sebagai pesan persuasi diarahkan untuk merubah sikap masyarakat sebagai audiens agar positif terhadap anggota dewan.

Berbicara soal efek persuasi tidak dapat dilepaskan dari teori elaboration likelihood dari Petty dan Cacciopo ${ }^{19}$. Teori persuasi yang memprediksi kapan dan bagaimana orang akan dapat dipersuasi atau tidak oleh informasi. Teori ini menjelaskan berbagai cara orang dalam mengevaluasi informasi yang diterima. Ada dua rute dalam memproses informasi yang digunakan berdasar kemampuan dan motivasi memproses informasi yaitu, rute sentral dan rute periferal. Ketika orang memproses informasi melalui rute sentral, orang menjadi aktif dan kritis. Sementara rute periferal digunakan untuk memproses informasi. Ketika orang memiliki motivasi yang rendah, orang cenderung menggunakan jarul periferal untuk memproses informasi. Motivasi antara lain terdiri dari keterlibatan, keberagaman argumen, serta predisposisi individu terkait berpikir kritis ${ }^{20}$.

Elaboration Likelihood Model (ELM) adalah pendekatan untuk memahami proses persuasi yang menggambarkan jalur pembuatan keputusan pada keyakinan, sikap, dan perubahan perilaku. Rute sentral adalah ketika konsumen memiliki keterlibatan tinggi dalam memproses informasi. Rute periferal adalah ketika konsumen memiliki keterlibatan rendah dalam memproses informasi. Ketika terjadi pergerakan melalui hirarki keterlibatan tinggi, konsumen menganalisa pesan yang diterima secara hati-hati dan membandingkannya pada posisi sikap konsumen. Ketika respon komunikasi cenderung menghasilkan sejumlah respon kognitif, tanda sentral merujuk pada gagasan dan data pendukung yang secara langsung

${ }^{18}$ Lim, Yon Soo \& Han Woo Park. "How Do Congressional Members Appear on The Web? Tracking the Web Visibility of South Korean Politicians.” Government Information Quarterly, 28 (2011): 514-521.

${ }^{19}$ Fill, Chris. Marketing Communications; Contexts, Contents, and Strategies (2nd Ed.). Barcelona: Prentice Hall Europe, 1999.

${ }^{20}$ Littlejohn, Stephen W \& Karen Foss. Theories of Human Communication (9th Ed.). Bellmont, California: Wadsworth, 2008. 73-75 
Diterbitkan oleh Program Studi IImu Komunikasi

Universitas Ahmad Dahlan Yogyakarta

memperlihatkan kualitas argumen yang dikembangkan dalam pesan. Saat konsumen bergerak melalui hirarki keterlibatan rendah, respon kognitif cenderung $\operatorname{minim}^{21}$.

Rute yang diaktifkan tergantung dari tingkat elaborasi yang dimiliki penerima pesan (pemikiran yang relevan terkait isu). Pertama, rute sentral, dimana outcome upaya persuasif sebagai hasil dari pemikiran mendalam dari penerima pesan atas isu materi yang relevan (misal: argumentasi pesan); ketika proses rute sentral yang terjadi, kualitas atau kekuatan argumen pesan cenderung menjadi kunci penentu suksesnya persuasi. Rute persuasi yang lain adalah rute periferal atau pinggir, dimana outcome persuasi muncul dari proses berpikir yang kurang mendalam, misal penerima menggunakan sebagian heuristik (aturan penyederhanaan keputusan); sebagai contoh, penerima pesan mengambil kesimpulan justru berdasar kredibilitas atau rasa suka pada komunikator atau berdasar reaksi orang lain terhadap pesan dan bukannya mempertimbangkan argumen dan bukti. Dua jalur tersebut bukanlah jalur yang eksklusif, tetapi lebih sebagai bentuk prototip yang merepresentasikan kontinum elaborasi yang ekstrim. Pada level elaborasi intermediate, rute sentral dan periferal dapat bekerja bersamaan ${ }^{22}$.

Rute sentral dan periferal berbeda tidak hanya pada penekanan atas faktor yang mempengaruhi hasil persuasi, tetapi juga pada penekanan terhadap konsekuensi atas segala persuasi yang diterapkan. Persuasi dicapai melalui proses rute sentral cenderung lebih bertahan (lebih membekas dalam waktu yang lama dan lebih resisten terhadap persuasi yang berlawanan) dan memiliki pengaruh yang lebih besar pada perilaku yang mengikuti dibanding saat persuasi dicapai melalui proses rute periferal ${ }^{23}$.

ELM menekankan perubahan sikap merupakan hasil dari satu atau dua rute pemrosesan, berdasar tingkat keterlibatan penerima pada pesan. Menurut Petty dan Cacioppo elaborasi adalah "pemikiran terkait isu". Individu dengan elaboration likelihood yang tinggi mengikat elaborasi yang ekstensif (pemrosesan jalur tengah) dari argumen terkait isu vs struktur sikap dan pengetahuan yang sudah ada dalam rangka menilai kualitas pesan yang sebenarnya. Argumen pesan adalah "unit-unit informasi” yang terkait dengan penilaian subyektif dari advokasi pesan.

\section{Pelaksanaan Fungsi DPRD}

DPRD adalah lembaga perwakilan rakyat yang berada di daerah (provinsi atau kabupaten/kota). Menurut calvin mackinzie ${ }^{24}$ lembaga perwakilan rakyat mempunyai tiga fungsi signifikan yaitu legislation, representation, dan administrative oversight. Berdasarkan Undang-Undang tentang Pemerintahan Daerah serta

\footnotetext{
${ }^{21}$ Mowen, John C. \& Michael Minor. Terj. Perilaku Konsumen Jilid I. Jakarta: Penerbit Erlangga, 2002.

22 O' Keefe, D. J. Theories of Persuasion. Dalam Oliver, M. B. \& R. Nabi (Eds.). Handbook of Media Effects. California: Sage Publications, 2009.

${ }^{23}$ Petty \& Wegner dalam O' Keefe, D. J. Theories of Persuasion. Dalam Oliver, M. B. \& R. Nabi (Eds.). Handbook of Media Effects. California: Sage Publications, 2009.

24 \& 28 Efriza. Studi Parlemen: Sejarah, Konsep, dan Lanskap Politik Indonesia. Malang: Setara Press, $2014,73-74$
} 
Undang-Undang tentang MPR, DPR, DPD, DPRD fungi DPRD adalah legislasi, budgeting, dan controlling.

Pelaksanaan fungsi DPRD tidak dapat dilepaskan dari kondisi anggota DPRD atau personalitas dari anggota DPRD yang kemudian akan mempengaruhi kinerja secara kelembagaan DPRD. Barbers ${ }^{25}$ mengkategorikan anggota parlemen dalam empat kelompok. Pertama adalah tipe lawmakers yakni mereka yang memiliki keaktifan dalam seluruh proses dan kegiatan di parlemen baik secara administrasi maupun secara substansi. Mereka juga memiiki keinginan untuk terus memperjuangkan idealismenya melalui parlemen.

Kedua adalah tipe advertisers, yakni mereka aktif dalam kegiatan parlemen baik secara subtansi dan administrasi namun mereka menganggap bahwa menjadi anggota parlemen adalah media untuk memperluas jaringan dan pencapaian pada jenjang kehidupan atau karir yang lebih baik. Sehingga seringkali mereka kemudian tidak bertahan lama sebagai anggota parlemen.

Ketiga, adalah tipe spectators. Mereka merupakan anggota parlemen yang tidak memiliki keaktifan dalam substansi proses kegiatan di parlemen. Keikutsertaan mereka di kegiatan parlemen hanyalah keikutsertaan secara administratif bahkan cenderung sebagai pengembira atau tidak mengambil peran yang substantif dalam proses di parlemen. Namun demikian mereka menikmati kondisi tersebut dan senantiasa berupaya untuk terus menjadi anggota parlemen.

Keempat, adalah tipe reluctants. Mereka merupakan orang-orang yang tidak aktif dalam proses di parlemen sementara pada saat yang sama mereka juga sudah tidak memiliki gairah untuk berada di parlemen. Keanggotaannya diparlemen lebih pada satu kewajiban dari partai yang harus dijalankannya.

Terkait dengan fungsi DPRD, setidaknya ada empat faktor yang mempengaruhi DPRD dalam menjalankan fungsinya, yakni ${ }^{26}$,

1) Integritas dan kemampuan atau keterampilan anggota legislatif

2) Pola hubungan anggota legislatif dengan anggota masyarakat yang mereka wakili yang tercermin dalam sistem perwakilan yang berlaku.

3) Struktur organisasi legislatif

4) Hubungan antara legislatif dengan eksekutif dan lembaga lainnya.

d. Metode Penelitian

Penelitian ini menggunakan paradigma post positivistik dengan metode kualitatif deskriptif. Metode kualitatif dilakukan untuk menjawab pertanyaan penelitian tentang komunikasi yang dilakukan oleh anggota dewan melalui media sosial mereka terkait pelaksanaan fungsi dewan sekaligus sikap masyarakat setelah terlibat dalam komunikasi dengan anggota dewan melalui media sosial. Pengambilan data untuk metode kualitatif dengan wawancara mendalam. Penelitian ini dilakukan di Jawa Tengah.

\footnotetext{
${ }^{25}$ Sanit, Arbi. Perwakilan Politik di Indonesia. Jakarta: Rajawali Press, 1985, 205.
} 
Diterbitkan oleh Program Studi IImu Komunikasi

Universitas Ahmad Dahlan Yogyakarta

Bagan 1.2. Alur Penelitian

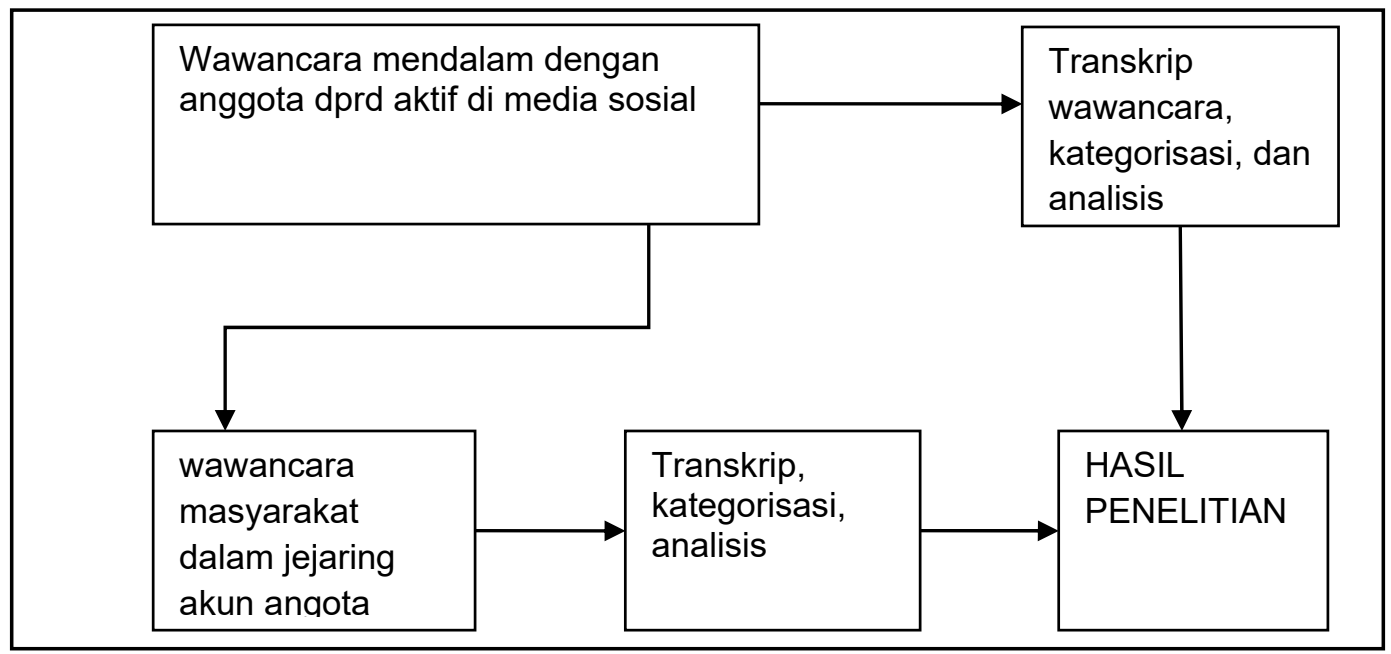

Penelitian ini diawali dengan memilih tiga anggota DPRD Jawa Tengah yang aktif memperbarui status di akun media sosial mereka. Ketiga anggota dewan tersebut diwawancara dengan teknik wawancara mendalam. Setelah melakukan wawancara mendalam, hasil wawancara akan ditranskrip untuk kemudian diklasifikasi dengan kategorisasi bukti dan kemudian dianalisis.

Peneliti lalu melihat daftar teman atau pengikut di jejaring sosial anggota dewan dan memilih subjek penelitian. Terdapat dua kelompok subjek dalam penelitian ini. Subjek pertama adalah anggota DPRD Jawa Tengah periode 2014-2019 yang aktif menggunakan media sosial untuk berkomunikasi dengan masyarakat. Anggota DPRD Jawa Tengah yang menjadi informan yaitu Riyono, Hadi Santoso, dan Muh Zen. Ketiganya aktif di Facebook dan menggunakan Facebook untuk mensosialisasikan berbagai aktivitas, baik yang terkait DPRD maupun yang tidak. Subjek kedua adalah masyarakat yang ada dalam jejaring media sosial anggota DPRD Jawa Tengah yang berhasil diwawancarai peneliti. Wawancara mendalam dilakukan terhadap informan yang menjadi teman ataupun jaringan dalam media sosial informan anggota dewan.

Pengumpulan data dilakukan melalui wawancara mendalam. Teknik wawancara ini digunakan untuk memperoleh data dari pertanyaan-pertanyaan yang tidak terstruktur dan bersifat open ended. Teknik ini dilakukan untuk mendapatkan data dari Anggota DPRD Jawa Tengah dan orang yang ada dalam jaringan media sosial anggota DPRD. Studi dokumentasi dan kepustakaan juga dilakukan sebagai teknik yang digunakan untuk mengumpulkan data-data sekunder.

Dalam melakukan analisis dan interpretasi data untuk metode kualitatif, penelitian ini menggunakan teknik analisis dan interpretasi data dengan membuat kategorisasi bukti, yaitu dengan membuat matriks kategori dan menempatkan bukti dalam kategori tersebut ${ }^{27}$.

${ }^{27}$ Yin, Robert K. (2005). Studi Kasus; Desain dan Metode. Jakarta: Rajawali Press 
Menurut Guba dan Lincoln ${ }^{28}$ kualitas data dalam penelitian yang menggunakan paradigma postpositivisme dilakukan dengan secara tegas dengan validitas internal dan eksternal, reliabilitas, dan objektivitas.

Menurut Miller ${ }^{29}$ paradigma postpositivisme juga mengandalkan kritik yang teliti dari komunitas akademisi agar objektivitas dapat terjaga dan memaksimalkan pertumbuhan ilmu pengetahuan sosial.

\section{B. Hasil dan Pembahasan}

\section{Media sosial dan Anggota DPRD Jawa Tengah}

Seluruh informan anggota dewan dalam penelitian ini menganggap penting aktivitas komunikasi dengan masyarakat. Komunikasi dengan masyarakat dipandang sebagai bagian dari kewajiban dewan untuk masyarakat yang diwakilinya. Kesadaran tersebut membuat anggota dewan selalu berupaya untuk mengkomunikasikan aktivitas kedewanannya. Informan menggunakan berbagai sarana yang memungkinkan untuk melakukan komunikasi dengan masyarakat.

Munculnya media sosial telah mempengaruhi lebih dari sekedar praktik komunikasi-itu telah memberikan platform baru yang besar untuk demokratisasi kepentingan dan gagasan dengan secara dramatis memperluas kesempatan bagi ekspresi bersaing dan ide-ide kontroversial di masyarakat. Dalam melakukan hal itu juga telah memperluas dan mengubah pentingnya hubungan masyarakat. Tidak ada lagi individu dan kelompok terhalang oleh kurangnya akses ke media cetak atau penyebaran terbatas agunan tersebut. Hari ini, individu dan organisasi dapat mempromosikan dan membujuk menggunakan berbagai platform dan alat-alat media sosial, berpotensi mencapai siapa pun di dunia maya. Dalam organisasi, tugas pemahaman dan memanfaatkan teknologi tersebut untuk mempromosikan dan membujuk sering berada di bawah kedok public relations. (Auger, 2013)

Media sosial secara utama adalah berinteraksi dengan orang lain dengan harapan mendapatkan balasan. Karaduman memodifikasi kategori media sosial yang dibuat oleh Kaplan dan Haenlein sebagai berikut ${ }^{30}$ : (Karaduman, 2013).

28 \& 31 Dalam Denzin, Norman K \& Yvonna S. Lincoln (Eds). (2005). The Sage Handbook Of Qualitative Research (3rd ed.). California: Sage Publication

29 \& 33 Karaduman, Ilkay. "The Effect of Social Media on Personal Branding Efforts of Top Level Executives." 99 (2013): 465-473, http://doi.org/10.1016/j.sbspro.2013.10.515 
Diterbitkan oleh Program Studi IImu Komunikasi Universitas Ahmad Dahlan Yogyakarta

Tabel 1 Kategori Media Sosial Kaplan dan Haenlein ${ }^{31}$

\begin{tabular}{|c|c|c|c|c|c|}
\hline \multicolumn{6}{|c|}{ Kehadiran Sosial/Media Richness } \\
\hline & & Rendah & Sedang & & Tinggi \\
\hline \multirow[t]{2}{*}{$\begin{array}{l}\text { Presentasi diri/ } \\
\text { pengungkapan } \\
\text { diri }\end{array}$} & Tinggi & Blog & $\begin{array}{l}\text { Jejaring } \\
\text { sosial. misal: } \\
\text { Facebook }\end{array}$ & $\begin{array}{ll}\text { Situs } & \text { mikro } \\
\text { blogging. } & \text { Misal: } \\
\text { Twitter } & \end{array}$ & $\begin{array}{l}\text { Dunia sosial } \\
\text { virtual. Misal: } \\
\text { Second Life }\end{array}$ \\
\hline & Rendah & $\begin{array}{l}\text { Proyek } \\
\text { kolaboratif. } \\
\text { Misal: } \\
\text { wikipedia }\end{array}$ & $\begin{array}{l}\text { Komunitas } \\
\text { konten. } \\
\text { Misal: } \\
\text { Youtube }\end{array}$ & $\begin{array}{l}\text { Situs } \\
\text { profesional. } \\
\text { Misal: Linkedln }\end{array}$ & $\begin{array}{l}\text { Dunia game } \\
\text { virtual. Misal: } \\
\text { World of Craft }\end{array}$ \\
\hline
\end{tabular}

Kategori di atas memperlihatkan bahwa Facebook menempati posisi media sosial dengan presentasi dan pengungkapan diri yang tinggi. Karenanya tidak mengherankan jika anggota dewan juga menggunakan Facebook sebagai media sosial utama untuk berkomunikasi dengan anggota dewan.

Anggota dewan menggunakan media sosial untuk beberapa kepentingan. Pertama, sebagai sarana mengkomunikasikan kinerja yang terkait fungsi dewan, yaitu, fungsi legislasi, pengawasan, dan anggaran. Kedua, media sosial sebagai media komunikasi dengan publik. Komunikasi dengan publik berfungsi untuk menyerap aspirasi, menyampaikan kinerja, dan sebagai bentuk pertanggungjawaban publik. Ketiga, sebagai sarana hiburan pengguna yang berfungsi untuk saluran ekspresi diri dan informasi aktivitas pribadi maupun keluarga.

Media sosial digunakan sebagai media sosialisasi atas aktivitas informan dalam menjalankan fungsi anggota dewan. Fungsi legislasi dan pengawasan adalah fungsi yang banyak dikomunikasikan melalui media sosial. Fungsi anggaran hanya dilakukan oleh satu informan. Selain digunakan terkait fungsi anggota dewan, media sosial juga digunakan oleh informan untuk mengkomunikasikan hal di luar kedewanan seperti berbagi informasi kegiatan, berbagi pandangan pribadi soal isu yang hangat diperbicangkan di masyarakat, maupun untuk berbagi sarana hiburan bagi sang pemilik akun.

Namun di satu sisi anggota dewan menyadari bahwa pesan terkait fungsi anggota dewan yang mereka bagi ke media sosial tidak mendapat respon sejauh yang mereka harapkan. Mereka menyadari bahwa pesan terkait fungsi anggota dewan yang mereka bagi cenderung dianggap tidak menarik untuk sebagian besar orang. Sehingga ketika orang hanya merespon dengan mengklik Like sudah dipandang sebagai respon yang sangat baik. Fungsi anggaran adalah fungsi yang paling jarang dikomunikasikan melalui media sosial. Hal tersebut dikarenakan rumitnya data yang harus diunggah dan dibutuhkan terkait fungsi anggaran.

Hasil riset menunjukkan bahwa informan anggota DPRD memandang media sosial sebagai media yang potensial untuk menjangkau pemilih dengan segala keterbatasan yang mereka miliki sebagai anggota DPRD. Karenanya informan anggota DPRD Jateng mengelola media sosial yang mereka miliki dengan serius. Mereka cenderung memilih untuk tidak berbagi hal-hal yang bersifat personal. Bahkan informan dari PKS mengelola sekaligus beberapa akun media sosial dan situs personal. Mereka memiliki website, akun 
di Facebook, Twitter, Instagram. Mengelola media sosial merupakan bagian dari kemampuan yang didorong oleh PKS untuk dimiliki kadernya di parlemen.

Pertanggungjawaban publik atas kinerjanya di DPRD Jawa Tengah. Bagi informan, sifat interaktif dari media sosial membuat mereka dengan cepat bisa melihat respon maupun feedback dari masyarakat informan. Meskipun informan anggota dewan mengakui bahwa respon dan feedback dari masyarakat terkait kinerja yang mereka sosialisasikan di media sosial belum sebaik yang mereka harapkan. Informan konstituen dalam jaringan media sosial anggota dewan menilai positif sosialisasi kegiatan dan gagasan terkait kinerja dewan. Mereka melihat komunikasi antara dewan dan rakyat yang diwakili bisa sangat cair melalui media sosial. Informan anggota dewan seringkali bertanya pendapat masyarakat, masyarakat pun tidak canggung menyampaikan aspirasinya. Penilaian positif informan masyarakat semakin baik ketika aspirasi yang mereka sampaikan di media sosial ditindaklanjuti melalui solusi nyata oleh informan anggota dewan.

Media sosial bisa menjadi bagian dari alat personal branding untuk anggota dewan. Personal branding merupakan proses dimana orang dan karir mereka dipandang sebagai brand dan dibedakan tujuannya dari manajemen reputasi dan manajemen kesan. Ia secara langsung ditujukan untuk menciptakan brand ekuitas dan aset yang membedakan ia dari orang lain. Biasanya upaya branding membutuhkan dukungan finansial yang ekstensif untuk mendukung promosi dalam menciptakan brand awareness dan selanjutnya brand loyalty. Media sosial dengan struktur ideologis dan teknologinya memberi kesempatan pada orang untuk mempromosikan dirinya sendiri sebagai brand dengan cara yang relatif mudah dan efisien ${ }^{32}$ (Karaduman, 2013).

\section{Sikap Masyarakat Atas Penggunaan Media Sosial Oleh Anggota DPRD Jawa Tengah}

Menurut Petty dan Cacioppo elaboration likelihood model (ELM) menguji pemrosesan sentral atas informasi sebagai pembentukan sikap didasarkan pada motivasi dan kemampuan orang untuk terlibat dengan pemikiran terkait pesan dan isu. Motivasi untuk terlibat dalam transaksi persuasif dihubungkan dengan faktor perhatian, kualitas pesan, keterlibatan orang dengan isu tersebut, dan kemampuan orang untuk memproses argumen persuasif. Hal ini berarti bahwa jika orang tidak peduli dengan sebuah topik, ia cenderung tidak akan menghabiskan banyak energi untuk memproses informasi dalam pesan persuasif tersebut. Orang seperti itu dapat diharapkan untuk mengandalkan isyarat periferal pesan tambahan, seperti daya tarik pelaku persuasi atau kredibilitasnya ${ }^{33}$.

Menurut Reinard jika penerima pesan secara personal peduli dengan topik, ia akan cenderung mencurahkan energi yang besar untuk memproses isi pesan. Pada perkembangannya, bukti juga menjadi penting. Karena jika bukti tersebut kuat, orang akan dipengaruhi olehnya. Dengan kata lain, menurut Pratkanis \& Turner ketika individu diha-

\footnotetext{
${ }^{32}$ Karaduman, Ilkay. "The Effect of Social Media on Personal Branding Efforts of Top Level Executives." 99 (2013): 465-473, http://doi.org/10.1016/j.sbspro.2013.10.515

33 \& 36 Jowett, Gartt S. \& Victoria O’Donnel. Propaganda and Persuasion. California: Sage Publications,Inc. 2006, 177
} 
Diterbitkan oleh Program Studi IImu Komunikasi

Universitas Ahmad Dahlan Yogyakarta

dapkan dengan situasi sosial yang nyata, ditunjukkan relevansi isu dengan hal-hal yang mereka perhatikan, refleksi, pemikiran kritis, dan tindakan lanjutan akan terjadi ${ }^{34}$.

Dalam perspektif elaboration likelihood model, informan masyarakat memiliki motivasi dan kemampuan yang tinggi untuk memproses informasi. Motivasi tersebut akibat adanya keterlibatan personal pada informan masyarakat dengan anggota dewan seperti kesamaan almamater maupun kesamaan daerah. Kemampuan tinggi untuk memproses informasi terjadi karena anggota aktif di media sosial. Sehingga pesan yang mereka kirimkan punya peluang dikonsumsi oleh informan masyarakat secara berulang dan utuh. Terlebih mengingat sifat media sosial seperti Facebook yang bisa diakses kapanpun dan menyimpan unggahan yang telah lewat. Dengan motivasi dan kemampuan memproses yang tinggi, masyarakat menggunakan jalur sentral untuk memprosen pesan yang dikirim oleh anggota dewan. Adanya sikap positif di awal yang muncul karena kesamaan daerah dan sekolah kemudian diteguhkan oleh adanya pandangan-pandangan yang mendukung dari materi yang diunggah anggota dewan. Pada akhirnya sikap yang muncul adalah sikap positif terhadap anggota dewan yang aktif di media sosial.

Semakin sering pesan diulang, semakin besar peluang seseorang untuk memikirkan konten pesan. Semakin seseorang mendapatkan gangguan, semakin rendah peluang orang untuk memikirkan pesan yang tengah berlangsung atau dikirimkan. Pesan yang tertulis menyajikan kesempatan yang lebih besar pada seseorang untuk mengelaborasi pesan dibandingkan dengan pesan audio. Hal itu terjadi karena orang dapat memroses pesan tertulis dengan cara mereka sendiri. Jika pesan tidak utuh atau jika orang tidak memiliki skema atau framework untuk dihubungkan dengan kepercayaan yang telah ada, maka kemampuan proses informasi tidak dapat muncul. Meskipun motivasi memproses informasi telah mencukupi ${ }^{35}$.

Semakin orang merasa bahwa pesan tersebut penting dan terkait dengan dirinya, maka semakin besar motivasi yang dimiliki untuk memproses atau memikirkan informasi tersebut. Dalam elaboration likelihood model, orang menjadi lebih termotivasi untuk memikirkan isi pesan ketika tahu bahwa mereka akan diwawancarai tentang isu tersebut. Ketika seseorang diberi tahu akan ditanyai tentang suatu isu, maka orang cenderung menganggap isu atau pesan terkait isu tersebut penting bagi dirinya. Sehingga motivasinya pun meningkat. Terkadang orang juga lebih termotivasi oleh informasi yang berbeda dengan yang biasa mereka hadapi dibandingkan dengan informasi yang cenderung sama ${ }^{36}$ (Petty dan Cacioppo, 1996: 265).

Motivasi antara lain terdiri dari keterlibatan atau relevansi personal, keberagaman argumen, serta predisposisi individu terkait berpikir kritis. Keterlibatan berarti semakin penting topik untuk seseorang, maka ia akan semakin termotivasi untuk memikirkan informasi tersebut. Keberagaman argumen berarti orang akan cenderung lebih memikirkan argumen yang berasal dari sumber yang bervariasi. Hal itu dikarenakan, ketika banyak orang membicarakan topik tersebut, seseorang tidak dapat memberikan penilaian dengan

\footnotetext{
35 Petty, Richard E. \& John T. Cacioppo. Attitude and Persuasion: Classic and Contemporary Approaches. Colorado: Westview Press, 1996, 265.

36 Petty, Richard E. \& John T. Cacioppo. Attitude and Persuasion: Classic and Contemporary Approaches. Colorado: Westview Press, 1996, 265.
} 
mudah. Ia akan termotivasi untuk lebih memikirkannya. Ketika banyak argumen dan banyak sumber dilibatkan dalam suatu topik, maka penerima cenderung termotivasi untuk berpikir lebih dalam. Individu yang terbiasa berpikir kritis akan termotivasi untuk memikirkan informasi dengan kritis pula. (Littlejohn\& Foss, 2008: 74)

Faktor-faktor seperti daya tarik dan keahlian sumber atau komunikator. Sedikitnya argumen yang disajikan, dan stimulus atau pengaruh positif atau negatif yang membentuk konteks dimana pesan disampaikan (misal: musik yang menyenangkan, daya tarik sumber, kelayakan sumber untuk dipercaya, dll). Efek kebenaran akan muncul ketika sesuatu diulang berkali-kali dan orang akan kemudian mempercayainya (Mowen \& Minor, 2002).

Penerima pesan mengambil kesimpulan justru berdasar kredibilitas atau rasa suka pada komunikator atau berdasar reaksi orang lain terhadap pesan dan bukannya mempertimbangkan argumen dan bukti (O'Keefe, 2009). Pada kemunculan tanda periferal, diharapkan informan masyarakat dapat mengambil kesimpulan yang menguntungkan dengan tidak mempertimbangkan pada argumen dan bukti.

Robert Cialdini dari Arizona State University membuat daftar isyarat atau tanda yang memicu respon pengambilan keputusan secara cepat ("click,whirr"), yaitu: (1) timbal balik atau balas jasa_-"anda berhutang pada saya"; (2) konsistensi-"kita selalu melakukan-ya dengan cara itu"; (3) bukti sosial—-"semua orang melakukannya"; (4) kesukaan"cintai saya, cintai gagasan saya"; (5) otoritas atau kekuasaan-"karena saya bilang begitu"; (6) kelangkaan-"cepat, sebelum semuanya habis". Isyarat tersebut merupakan isyarat periferal. Petty dan Cacioppo menjabarkan kredibilitas pembicara, reaksi orang lain, dan penghargaan (rewards) eksternal merupakan bagian dari isyarat periferal (Griffin, 2003: 198).

Sifat pemrosesan kognitif terdiri dari sikap awal dan kualitas argumen. Sifat argumen dalam pesan: secara subyektif kuat (pandangan menyenangkan yang terlatih), secara subyektif lemah (pandangan tidak menyenangkan yang terlatih), secara subyektif ambigu. Sifat advokasi: kontra sikap (pandangan tidak menyenangkan yang terlatih), pro sikap (pandangan menyenangkan yang terlatih), dan netral. Ketika orang memaknai bahwa pesan memiliki argumen yang kuat dan menarik, maka memikirkan argumen menimbulkan pandangan terlatih yang menyenangkan. Sebaliknya ketika orang menilai bahwa pesan mengandung argumen yang lemah, maka memikirkan argumen akan menghasilkan argumen kontra yang terlatih. Orang bisa saja langsung bersikap jauh dari yang diharapkan ${ }^{37}$.

Penerima pesan mengidentifikasi argumen yang lemah dan dipengaruhi oleh argumen yang kuat. Dalam rute sentral, argumen dinilai dan dievaluasi dengan hati-hati ${ }^{38}$. Sehingga argumentasi yang muncul merupakan hasil dari pemrosesan kognitif yang baik.

Pemrosesan kognitif menekankan pada isi pesan yang berkualitas dan memiliki argumentasi yang dapat membuat penerima pesan berpikir ${ }^{39}$. Menurut Petty dan

37 Petty, Richard E. \& John T. Cacioppo. Attitude and Persuasion: Classic and Contemporary Approaches. Colorado: Westview Press, 1996, 256-265.

${ }^{38}$ Littlejohn, Stephen W \& Karen Foss. Theories of Human Communication (9th Ed.). Bellmont, California: Wadsworth, 2008 .

${ }^{39}$ Fill, Chris. Marketing Communications; Contexts, Contents, and Strategies (2nd Ed.). Barcelona: Prentice Hall Europe. 1999, 275. 
Diterbitkan oleh Program Studi IImu Komunikasi

Universitas Ahmad Dahlan Yogyakarta

Cacioppo ${ }^{40}$ argumentasi yang kuat menghasilkan pandangan atau pemikiran yang menyenangkan saat didengarkan dan diamati. Mereka memprediksi bahwa pertimbangan yang matang akan pesan yang kuat akan menghasilkan perubahan sikap yang besar sesuai harapan dari pengirim pesan. Selain kualitas argumen, pemrosesan kognitif juga didasarkan pada sikap awal penerima pesan.

Hasil penelitian menunjukkan bahwa komunikasi yang dilakukan anggota DPRD Jawa Tengah melalui media sosial diproses menggunakan jalur sentral oleh informan masyarakat. Hal tersebut terjadi karena adanya motivasi dan kemampuan memproses pesan pada penerima pesan. Motivasi muncul karena adanya kesamaan antara pengirim dan penerima pesan, yaitu kesamaan wilayah asal maupun kesamaan sekolah. Keterkaitan pada latar belakang pengirim dan penerima pesan membuat penerima pesan memiliki motivasi untuk memproses komunikasi melalui medai sosial.

Sementara kemampuan memproses komunikasi muncul karena adanya informan anggota dewan secara konsisten memperbarui status di media sosial mereka. Sifat media sosial yang meninggalkan jejak juga memudahkan penerima pesan untuk menelusuri kembali pesan-pesan yang pernah dikirimkan oleh informan anggota dewan. Dengan adanya motivasi dan kemampuan memproses informasi, maka terjadilah pemrosesan kognitif. Pemrosesan kognitif juga melibatkan sikap awal dari penerima pesan.

Karena adanya kesamaan latar belakang antara penerima dan pengirim pesan, sikap awal penerima pesan cenderung positif terhadap pengirim pesan. Kondisi tersebut kemudian menghasilkan pemrosesan melalui jalur sentral yang berujung pada sikap positif terhadap anggota dewan yang aktif di media sosial. Informan masyarakat melihat bahwa anggota dewan yang aktif di media sosial adalah mereka yang benar-benar bekerja dan layak mendapat kepercayaan masyarakat. Sehingga perubahan sikap yang terjadi pada informan masyarakat adalah semakin positif terhadap anggota dewan yang aktif di media sosial.

Bagan berikut menunjukkan bagaimana sikap informan masyarakat terbentuk dalam konteks elaboration likelihood model.

${ }^{40}$ Dalam Griffin, Emory A. A First Look at Communication Theory. (5th Ed). New York: McGraw Hill Companies. 2003, 199-201. 


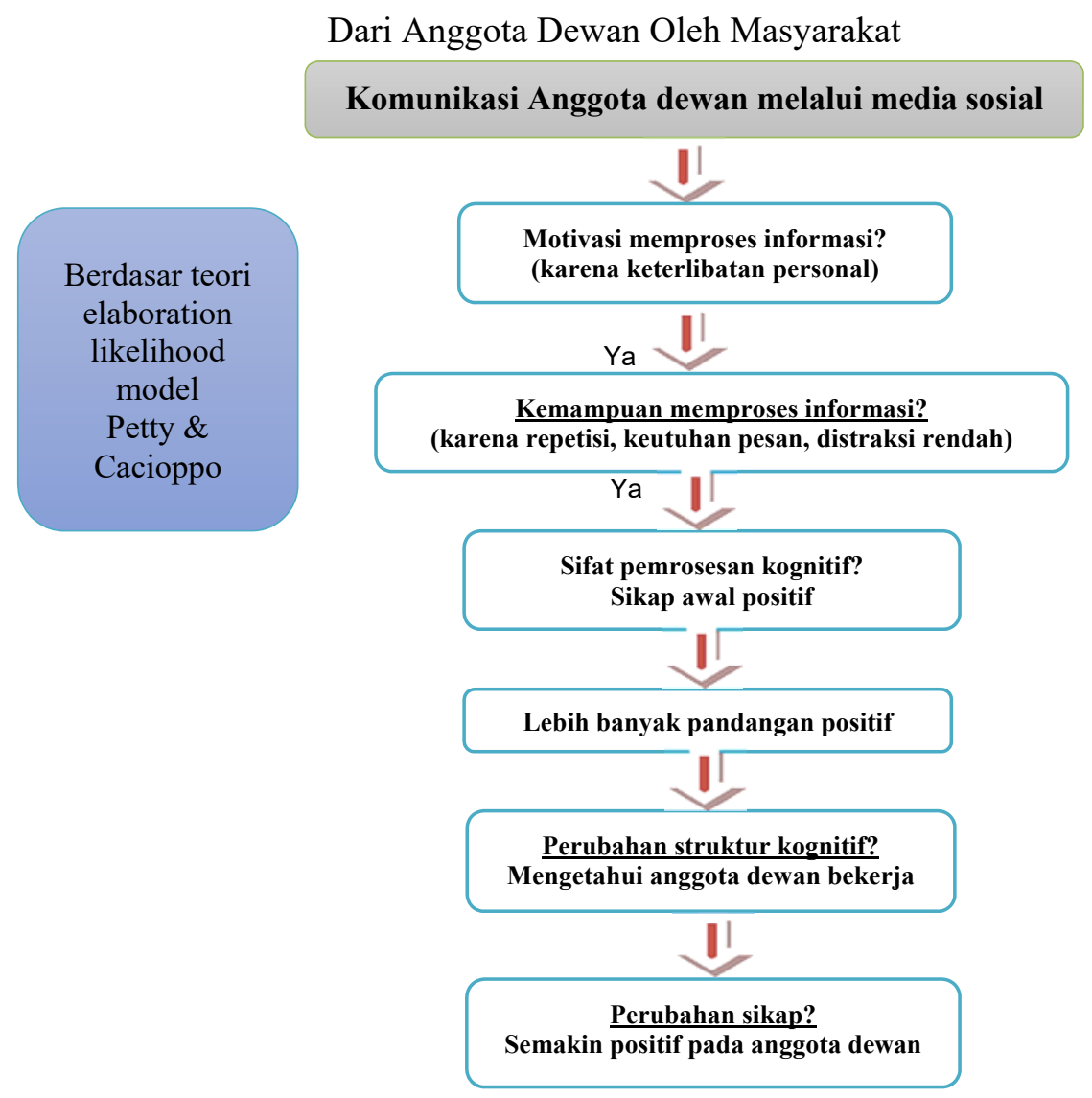

Sumber: Hasil Penelitian Penulis

Media sosial digunakan oleh anggota DPRD Jawa Tengah untuk tiga hal, antara lain: (1) mengkomunikasikan fungsi dewan (legislasi, pengawasan, dan anggaran); (2) berkomunikasi dengan publik dalam rangka mendengar aspirasi dan mendapatkan masukan; (3) sarana hiburan yang diwujudkan dengan menggunakan media sosial sebagai penyaluran ekspresi diri dan informasi kegiatan pribadi maupun dengan keluarga.

Terkait fungsi dewan yang dikomunikasikan melalui media sosial, fungsi pengawasan merupakan fungsi yang paling sering dilakukan. Sementara fungsi legislasi dilakukan secara moderat, dan fungsi anggaran sebagai fungsi yang paling jarang dikomunikasikan.

Informan masyarakat yang ada dalam jaringan media sosial anggota DPRD Jawa Tengah yang aktif di media sosial mempersepsikan anggota dewan tersebut sebagai wakil rakyat yang benar-benar bekerja untuk rakyat. Persepsi positif tersebut muncul bersamaan dengan feedback yang minim atas aktivitas anggota DPRD Jawa Tengah di media sosial. Informan masyarakat menyatakan bahwa mereka mempersepsikan positif namun jarang memberikan umpan balik terhadap hal-hal yang diunggah anggota dewan. 
Diterbitkan oleh Program Studi IImu Komunikasi

Universitas Ahmad Dahlan Yogyakarta

Bagan 2. Evaluasi Pemanfaatan Media Sosial

Bagi Pelaksanaan Fungsi Anggota DPRD Jawa Tengah

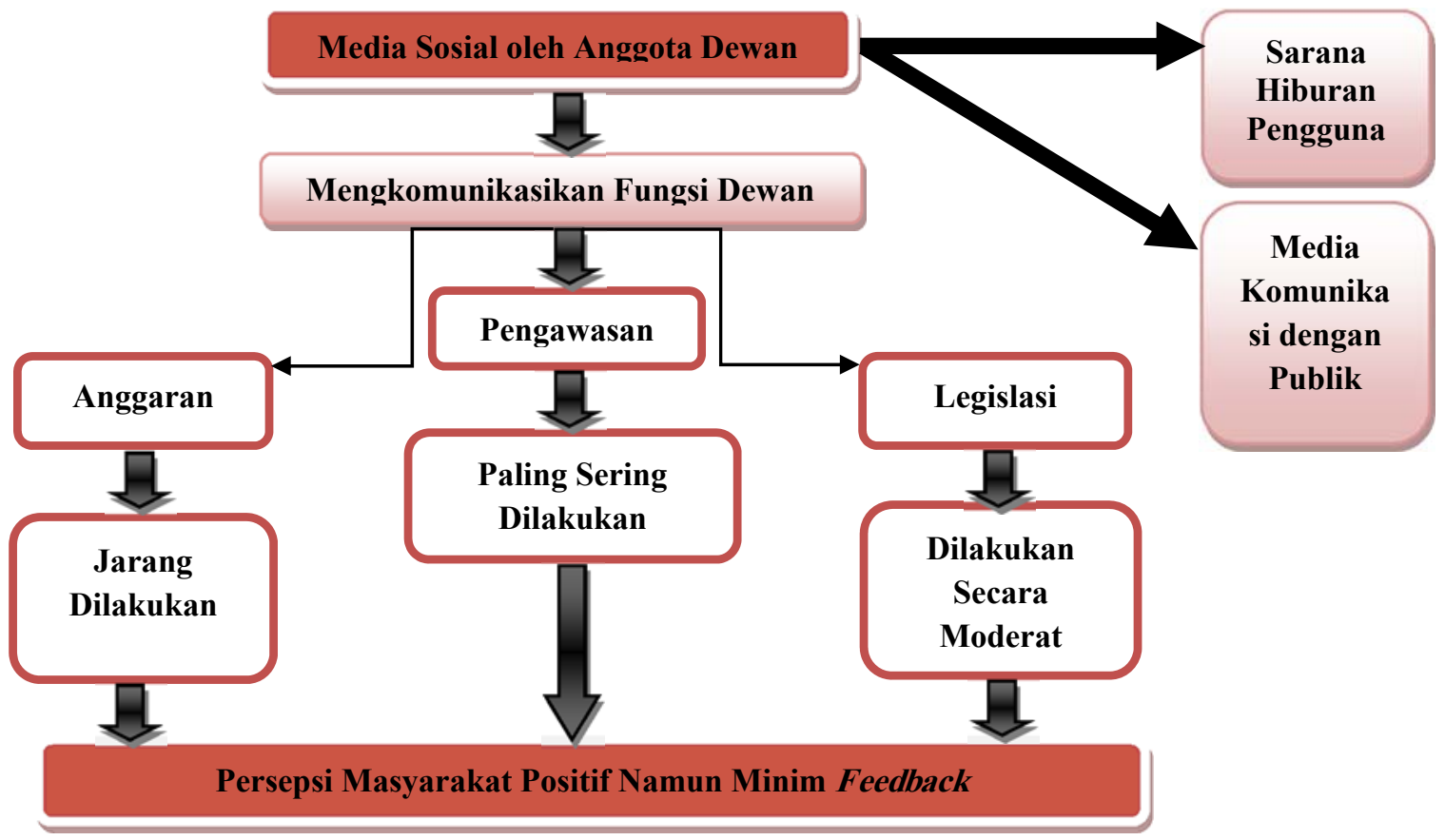

Sumber: Hasil Penelitian Penulis

\section{Kesimpulan}

Media sosial digunakan oleh anggota DPRD Jawa Tengah untuk tiga hal, antara lain: (1) mengkomunikasikan fungsi dewan (legislasi, pengawasan, dan anggaran); (2) berkomunikasi dengan publik dalam rangka mendengar aspirasi dan mendapatkan masukan; (3) sarana hiburan yang diwujudkan dengan menggunakan media sosial sebagai penyaluran ekspresi diri dan informasi kegiatan pribadi maupun dengan keluarga.

Terkait fungsi dewan yang dikomunikasikan melalui media sosial, fungsi pengawasan merupakan fungsi yang paling sering dilakukan. Sementara fungsi legislasi dilakukan secara moderat, dan fungsi anggaran sebagai fungsi yang paling jarang dikomunikasikan.

Informan masyarakat yang ada dalam jaringan media sosial anggota DPRD Jawa Tengah yang aktif di media sosial mempersepsikan anggota dewan tersebut sebagai wakil rakyat yang benar-benar bekerja untuk rakyat. Persepsi positif tersebut muncul bersamaan dengan feedback yang minim atas aktivitas anggota DPRD Jawa Tengah di media sosial. Informan masyarakat menyatakan bahwa mereka mempersepsikan positif namun jarang memberikan umpan balik terhadap hal-hal yang diunggah anggota dewan.

Dalam perspektif elaboration likelihood model, informan masyarakat memiliki motivasi dan kemampuan yang tinggi untuk memproses informasi. Motivasi tersebut akibat adanya keterlibatan personal pada informan masyarakat dengan anggota dewan seperti kesamaan almamater maupun kesamaan daerah. Kemampuan tinggi untuk memproses informasi terjadi karena anggota aktif di media sosial. Sehingga pesan yang mereka 
kirimkan punya peluang dikonsumsi oleh informan masyarakat secara berulang dan utuh. Terlebih mengingat sifat media sosial seperti Facebook yang bisa diakses kapanpun dan menyimpan unggahan yang telah lewat. Dengan motivasi dan kemampuan memproses yang tinggi, masyarakat menggunakan jalur sentral untuk memprosen pesan yang dikirim oleh anggota dewan. Adanya sikap positif di awal yang muncul karena kesamaan daerah dan sekolah kemudian diteguhkan oleh adanya pandangan-pandangan yang mendukung dari materi yang diunggah anggota dewan. Pada akhirnya sikap yang muncul adalah sikap positif terhadap anggota dewan yang aktif di media sosial.

\section{Daftar Pustaka}

Abdulrahman, Wahid. Evaluasi Masa Reses DPRD Jawa Tengah. Tesis. Magister Ilmu Politik Universitas Diponegoro, 2011. (unpublished)

Abdulrahman, Wahid. "Evaluasi Badan Legislasi DPRD Jawa Tengah.” Politika: Jurnal Ilmu Politik. ISSN: 2086-7344, Magister Ilmu Politik Program Pascasarjana Universitas Diponegoro, 2015.

Auger, G. A. "Public Relations Review Fostering Democracy Through Social Media: Evaluating Diametrically Opposed Nonprofit Advocacy Organizations Use of Facebook, Twitter, and YouTube." Public Relations Review 39(4) (2013): 369376, http://doi.org/10.1016/j.pubrev.2013.07.013

Bernecker, Andreas. "Do Politicians Shirk when Relection is Certain? Evidence from The German Parliament." European Journal of Political Economy 36 (2014): 55-70.

Efriza. Studi Parlemen: Sejarah, Konsep, dan Lanskap Politik Indonesia. Malang: Setara Press, 2014.

Fill, Chris. Marketing Communications; Contexts, Contents, and Strategies (2nd Ed.). Barcelona: Prentice Hall Europe, 1999.

Griffin, Emory A. A First Look at Communication Theory. (5th Ed). New York: McGraw Hill Companies. 2003

Jowett, Gartt S. \& Victoria O'Donnel. Propaganda and Persuasion. California: Sage Publications, Inc. 2006.

Karaduman, Ilkay. "The Effect of Social Media on Personal Branding Efforts of Top Level Executives." 99 (2013): 465-473, http://doi.org/10.1016/j.sbspro.2013.10.515

Kiambi, Dane. "Ethnic Appeal: A Self-defense Tool for Kenyan Politicians." Public Relations Review, 38 (2012): 144-146.

Lailiyah, Nuriyatul. Komunikasi Strategis dalam Pemilukada: Studi Kasus Kemenangan Widya Kandi-Mustamsikin dalam Pemilukada Kabupaten Kendal. Tesis. Magister Ilmu Komunikasi Universitas Diponegoro, 2011. (Unpublished)

Lailiyah, Nuriyatul. "Strategi Media Relations Politisi untuk Meraih Popularitas di Media Massa." Politika: Jurnal Ilmu Politik vol 6 (1 April 2015): 93-103, ISSN: 20867344 Magister Ilmu Politik Program Pascasarjana Universitas Diponegoro.

Lim, Yon Soo \& Han Woo Park. "How Do Congressional Members Appear on The Web? Tracking the Web Visibility of South Korean Politicians." Government Information Quarterly, 28 (2011): 514-521. 
Diterbitkan oleh Program Studi IImu Komunikasi

Universitas Ahmad Dahlan Yogyakarta

Littlejohn, Stephen W \& Karen Foss. Theories of Human Communication (9th Ed.). Bellmont, California: Wadsworth, 2008.

Mowen, John C. \& Michael Minor. Terj. Perilaku Konsumen Jilid I. Jakarta: Penerbit Erlangga, 2002.

O’ Keefe, D. J. Theories of Persuasion. Dalam Oliver, M. B. \& R. Nabi (Eds.). Handbook of Media Effects. California: Sage Publications, 2009.

Petty, Richard E. \& John T. Cacioppo. Attitude and Persuasion: Classic and Contemporary Approaches. Colorado: Westview Press, 1996.

Sanit, Arbi. Perwakilan Politik di Indonesia. Jakarta: Rajawali Press, 1985.

Yin, Robert K. (2005). Studi Kasus; Desain dan Metode. Jakarta: Rajawali Press

Antara. "Hasil Riset, ini Jumlah Rata-rata Dana Kampanye Caleg DPR.",

Republika, 19 Maret 2014, http://www.republika.co.id/berita/nasional/politik/14/03/19/n2o11c-hasil-riset-ini-jumlahratarata-dana-kampanye-caleg-dpr

Ayudea, Fani. "Anggota DPRD Harus Punya Akun Media Sosial." Suara Merdeka, 11 Februari 2016, http://berita.suaramerdeka.com/anggota-dprd-harus-punya-akunmedia-sosial/

Budilaksono, Imam. "90,5\% Anggota DPR Mencalonkan Kembali.”, Antara News, 5 Maret 2013, http://www.antaranews.com/berita/373085/905-persen-anggota-dprmencalonkan-kembali

Humas. "DPRD Jateng Menuju Parlemen Terbuka.", 10 Februari 2016, http://wartalegislatif.dprd.jatengprov.go.id/post/dprd-jateng-menuju-parlementerbuka 